\title{
OCEAN STATE ESTIMATION FOR CLIMATE RESEARCH
}

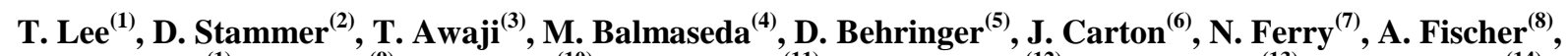
I. Fukumori $^{(1)}$, B. Giese ${ }^{(9)}$, K. Haines ${ }^{(10)}$, E. Harrison ${ }^{(11)}$, P. Heimbach ${ }^{(12)}$, M. Kamachi ${ }^{(13)}$, C. Keppenne ${ }^{(14)}$,

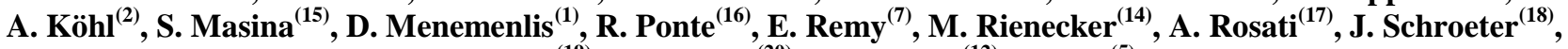
D. Smith ${ }^{(19)}$, A. Weaver ${ }^{(20)}$, C. Wunsch ${ }^{(12)}$, Y. Xue ${ }^{(5)}$

(1) NASA (National Aeronautics and Space Administration) Jet Propulsion Laboratory, California Institute of Technology, 4800 Oak Grove Dr, Pasadena, CA 91109, USA. Email: Tong.Lee@jpl.nasa.gov;

Fukumori@jpl.nasa.gov; Menemenlis@jpl.nasa.gov

(2) Institut für Meereskunde, KlimaCampus, University of Hamburg, Bundesstr. 53, 20146 Hamburg, Germany. Email: detlef.stammer@zmaw.de; armin.koehl@zmaw.de

(3) Division of Earth and Planetary Sciences, Graduate School of Science, Kyoto University, Kyoto 606-8502, Japan. Email: awaji@kugi.kyoto-u.ac.jp

(4) European Centre for Medium-Range Weather Forecast, ECMWF, Shinfield Park, Reading RG2 9AX, UK. Email: Magdalena.Balmaseda@ecmwf.int

(5) NOAA (National Oceanic and Atmospheric Administration)/National Centers for Environmental Prediction, 5200 Auth Rd, Camp Springs, MD 20746-4304, USA. Email: David.Behringer@noaa.gov; Yan.Xue@noaa.gov

(6) Department of Atmospheric and Oceanic Science, University of Maryland, 3413 Computer \& Spaces Sci. Bldg., University of Maryland, College Park, MD 20742, USA

(7) Mercator-Océan, 8-10 rue Hermès, 31520 Ramonville, St Agne, France. Email: nicolas.ferry@mercator-ocean.fr; Elisabeth.Remy@mercator-ocean.fr

(8) Intergovernmental Oceanographic Commission, UNESCO (United Nations Educational, Scientific and Cultural Organization), 1 rue Miollis, 75732 Paris Cedex 15, France. Email: a.fischer@unesco.org

(9) Department of Oceanography, Texas A\&M University, College Station, TX 77843-3146, USA. b-giese@tamu.edu

(10) Reading University, Marine Informatics and Reading e-Science Centre, ESSC, Harry Pitt Bld, 3 Earley Gate, Reading University, Reading RG6 6AL, UK. Email: kh@mail.nerc-essc.ac.uk

(11) NOAA (National Oceanic and Atmospheric Administration)/Pacific Marine Environmental Laboratory/OCRD (Office Chief of Research and Development), 7600 Sand Point Way NE, Seattle, WA 98115, USA.

Email: D.E.Harrison@noaa.gov

(12) Massachusetts Institute of Technology, Department of Earth, Atmospheric and Planetary Sciences,

77 Massachusetts Avenue, Department of Earth, Atmospheric and Planetary Sciences, MIT, MA 02139 USA. Email: Heimbach@mit.edu; cwunsch@mit.edu

(13) Oceanographic Research Department, Meteorological Research Institute, 1-1 Nagamine, Tsukuba 305-0052, Japan.Email: mkamachi@mri-jma.go.jp

(14) NASA (National Aeronautics and Space Administration) Goddard Space Flight Center, Global Modeling and Assimilation Office, 8463 Greenbelt Rd, Greenbelt, MD 20770-25481, USA. Email: christian.keppenne@nasa.gov; Michele.Rienecker@nasa.gov

(15) Centro Euro-Mediterraneo per i Cambiamenti Climatici and Istituto Nazionale di Geofisica e Vulcanologia, Viale A. Moro 44, 40127 Bologna, Italy Email: masina@bo.ingv.it

(16) Atmospheric and Environmental Research, Cambridge, Massachusetts, USA. Email: rponte@aer.com

(17) NOAA (National Oceanic and Atmospheric Administration)/Geophysics Fluid Dynamics Laboratory, Princeton University Forrestal Campus

201 Forrestal Road, Princeton, NJ 08540-6649, USA. Email: Tony.Rosati@noaa.gov

(18) Alfred-Wegener-Institute for Polar and Marine Research, Postfach 1201 61, 27515 Bremerhaven, Germany. Email: jens.schroeter@awi.de

(19) Met Office Hadley Centre, FitzRoy Road, Exeter, EX1 3PB, UK. doug.smith@metoffice.gov.uk

(20) Centre Européen de Recherche et de Formation Avancée en Calcul Scientifique, 42 avenue Gaspard Coriolis, 31057 Toulouse, France, Email: weaver@cerfacs.fr

\begin{abstract}
Spurred by the sustained operation and new development of satellite and in-situ observing systems, global ocean state estimation efforts that gear towards climate applications have flourished in the past decade. A hierarchy of estimation methods is being used to routinely synthesize various observations with global
\end{abstract}

ocean models. Many of the estimation products are available through public data servers. There have been an increasingly large number of applications of these products for a wide range of research topics in physical oceanography as well as other disciplines. These studies often provide important feedback to the observing systems. This white paper describes the approaches used by the estimation systems in synthesizing observations 
and model dynamics, highlights the applications of their products for climate research, and addresses the challenges ahead in relation to the observing systems. Further applications to study climate variability using ENSEMBLE state estimation products are described by a white paper by Stammer et al. (2010).

\section{INTRODUCTION}

As satellite and in-situ observing systems for the global ocean (e.g. altimetry and Argo) progress and mature with time, there is an ever-increasing need to synthesize the diverse observations by using them to constrain state-of-the-art ocean general circulation models (OGCMs). The resulting ocean state estimation products aim to provide estimates of the time-varying, threedimensional state of the ocean and to help understand the variability of ocean circulation and its relation to climate. They offer a tool to estimate quantities that are difficult to infer from observations alone, such as oceanic heat transport.

The vision of global ocean state estimation as a means to synthesize ocean observations into a dynamically consistent estimate of the ocean circulation was developed under the "World Ocean Circulation Experiment" (WOCE) and was further developed as part of WCRP's “Climate Variability and Predictability Project" (CLIVAR) and Global Ocean Data Assimilation Experiment (GODAE). As a result of this, and with the sustained commitment of various funding agencies, climate-oriented ocean state estimation efforts have flourished in the past decade. Since OceanObs'99, many ocean state estimation systems have been developed to routinely produce estimates of the physical state of the ocean that are publically available through data servers. State estimation products have been used to study a wide range of topics in physical oceanography and climate-related phenomena as well as in geodesy and biogeochemistry.

\section{APPROACHES}

A hierarchy of estimation methods has been adopted by various groups to perform ocean state estimation, ranging from sequential or filter methods such as objective mapping or the so-called optimal interpolation (OI), 3-dimensional variational (3D-VAR) method, and Kalman filter, to the so-called "smoother" methods such as the Green's function, Rauch-Tung-Striebel (RTS) smoother, and the adjoint method (a.k.a. Lagrange multiplier, Pontryagin's principle, 4-dimensional variational or 4D-VAR). Table 1 lists the estimation methods used by various systems, many of which have a focus on climate applications (for diagnostic analysis, initialization of climate prediction, or both).
In sequential estimation, the estimated state at a certain time is influenced by observations up to that time. In smoother methods, however, the estimated state at any time is affected by observations in the future as well as in the past and present. The sequential methods as implemented various assimilation groups by are typically computationally more efficient than smoother methods such as the adjoint. The sequential approaches allow the estimated state to deviate from an exact solution of the underlying physical model by applying statistical corrections to the state, which is often based on some basic physical constraints (such as preservation of the water mass properties, geostrophic balance, etc.). These corrections are meant to compensate a combination of various errors in model physics (including forcing), such as errors in the representation of advection and mixing, errors due to lack of resolution, erroneous bathymetry, and missing physical processes. Because they do not explicitly describe the correction of a specific physical process, these corrections imply internal sources and sinks of heat, salt, and momentum, etc., which tend to render the estimated state closer to the observations being assimilated (depending on the treatment of the model and data errors).

Adjoint-based estimation systems often demand the estimated state to satisfy the model equations exactly over a certain time interval. The optimization of the state within such a time interval is accomplished by adjusting the control variables, which are typically the initial state, surface forcing, and model parameters. Not having internal source and sink allows the so-called physical consistency, namely, the consistency of the estimated surface forcing with the estimated ocean state and the closure of property budgets, which greatly facilitates many aspects of climate research such as heat balance and diagnosis of the relative roles of different surface forcing on the ocean. The adjoint approach is adopted by the Consortium of Estimating the Circulation and Climate of the Ocean (ECCO, Stammer et al. 2002a) and Japan's K-7 project (Sugiura et al. 2008) (Tab. 1). Nevertheless, the lack of internal sources and sinks in the adjoint approach could make it more difficult for the model to fit certain aspects of the observations, especially over a long integration. In this case, it is important to identify and implement internal control variables so as to correct model error that the initial state and surface forcing cannot account for. Examples of such internal control variables include the mixing coefficients (e.g. Stammer 2005) or an "eddy stress" to represent the effect of mesoscale eddies that are not resolved by coarse resolution models. The adjoint method itself is amendable to the introduction of internal control variables. 


\begin{tabular}{|c|c|c|c|c|}
\hline System & Method & Data & Period & Server \\
\hline $\begin{array}{l}\text { ECCO-GODAE } \\
\text { (MIT-AER), } \\
\text { USA }\end{array}$ & Adjoint & $\begin{array}{l}\text { Altimetry; scatterometry; tide } \\
\text { gauges; gravity; SST, SSS; T \& } \\
\text { S profiles from XBT, CTD, } \\
\text { Argo, TAO \& other buoys, } \\
\text { elephant seals (SeaOS); Florida } \\
\text { Current; RAPID array }\end{array}$ & $1992-2008$ & www.ecco-group.org \\
\hline ECCO1, USA & Adjoint & $\begin{array}{l}\text { Altimetry; scatterometry; tide } \\
\text { gauges; geoid; SST, SSS; T \& } \\
\text { S profiles from XBT, CTD, } \\
\text { Argo, TAO \& other buoys,. }\end{array}$ & $1992-2001$ & www.ecco-group.org \\
\hline $\begin{array}{l}\text { G-ECCO, } \\
\text { Germany }\end{array}$ & Adjoint & $\begin{array}{l}\text { Altimetry; scatterometry; tide } \\
\text { gauges; geoid; SST, SSS; T \& } \\
\text { S profiles from XBT, CTD, } \\
\text { Argo, TAO \& other buoys,. }\end{array}$ & $1952-2001$ & www.ecco-group.org \\
\hline ECCO-JPL, USA & $\begin{array}{l}\text { Kalman } \\
\text { filter \& RTS } \\
\text { smoother }\end{array}$ & $\begin{array}{l}\text { Altimetry, } \mathrm{T} \text { profiles from } \\
\text { XBT/CDT, Argo, and TAO. }\end{array}$ & 1993-present & $\begin{array}{l}\text { www.ecco-group.org or } \\
\text { www.ecco.jpl.nasa.gov/external }\end{array}$ \\
\hline ECCO2, USA & $\begin{array}{l}\text { Green's } \\
\text { functions }\end{array}$ & $\begin{array}{l}\text { Altimetry, SST, T \& S profiles } \\
\text { from XBT, CTD, Argo, TAO; } \\
\text { sea ice data }\end{array}$ & $1992-2008$ & www.ecco2.org \\
\hline $\begin{array}{l}\text { GMAO/NASA, } \\
\text { USA }\end{array}$ & $\begin{array}{l}\text { OI, } \\
\text { ensemble } \\
\text { Kalman } \\
\text { filter }\end{array}$ & $\begin{array}{l}\text { Altimetry, T \& S profiles from } \\
\text { XBT, CTD, Argo, TAO }\end{array}$ & 1993-present & $\begin{array}{l}\text { gmao.gsfc.nasa.gov/research/ocean } \\
\underline{\text { assim// }}\end{array}$ \\
\hline $\begin{array}{l}\text { GFDL/NOAA, } \\
\text { USA }\end{array}$ & $\begin{array}{l}\text { Coupled } \\
\text { Data } \\
\text { Assimilation } \\
\text { (Ensemble } \\
\text { Kalman } \\
\text { Filter) }\end{array}$ & $\begin{array}{l}\text { SST, } \mathrm{T} \text { profiles from XBT, } \\
\text { CTD, Argo, TAO \& S profiles } \\
\text { from CTD, Argo }\end{array}$ & $1979-2008$ & $\begin{array}{l}\text { Data1.gfdl.noaa.gov/nomads/forms/ } \\
\text { assimilation.html }\end{array}$ \\
\hline $\begin{array}{l}\text { GODAS, } \\
\text { NCEP/NOAA, } \\
\text { USA }\end{array}$ & 3D-VAR & $\begin{array}{l}\text { SST, } \mathrm{T} \text { profiles from XBT, } \\
\text { CTD, Argo, TAO }\end{array}$ & 1979-present & $\begin{array}{l}\text { www.cpc.ncep.noaa.gov/products/ } \\
\underline{\text { GODAS }}\end{array}$ \\
\hline SODA, USA & OI & $\begin{array}{l}\text { Altimetry, Satellite and in-situ } \\
\text { SST, T \& S profiles from } \\
\text { MBT, XBT, CTD, Argo and } \\
\text { other float data, TAO and other } \\
\text { buoys. }\end{array}$ & $1958-2007$ & $\begin{array}{l}\text { www.atmos.umd.edu/ ocean/data.h } \\
\text { tml or soda.tamu.edu }\end{array}$ \\
\hline $\begin{array}{l}\text { ORA-S3 } \\
\text { ECMWF, EU }\end{array}$ & $\begin{array}{l}\text { 3D OI with } \\
\text { online bias } \\
\text { correction }\end{array}$ & $\begin{array}{l}\text { Altimeter (sea level anomalies } \\
\text { and global trends), SST, T \& S } \\
\text { from XBT, CTD, Argo, TAO }\end{array}$ & 1959-present & $\begin{array}{l}\text { Graphical: } \\
\text { www.ecmwf.int/products/forecasts/ } \\
\text { d/charts/ocean/reanalysis } \\
\text { Data: } \\
\text { ensembles.ecmwf.int/thredds/ocean } \\
\text { lecmwf/catalog.html }\end{array}$ \\
\hline $\begin{array}{l}\text { MERCATOR, } \\
\text { France }\end{array}$ & SEEK filter & $\begin{array}{l}\text { Altimetry, SST, T \& S from } \\
\text { XBT, CTD, Argo, TAO }\end{array}$ & 1980-present & www.mercator-ocean.fr \\
\hline CERFACS, France & 3D-VAR & SST, T \& S profiles from EN3 & $1960-2006$ & $\begin{array}{l}\text { http://www.ecmwf.int/research/EU } \\
\text { projects/ENSEMBLES/data/data } \\
\text { dissemination.html }\end{array}$ \\
\hline
\end{tabular}




\begin{tabular}{|c|c|c|c|c|}
\hline INGV, Italy & OI & $\begin{array}{l}\text { SST, T \& S profiles from XBT, } \\
\text { CTD, Argo, TAO }\end{array}$ & $1958-2006$ & $\begin{array}{l}\text { www.bo.ingv.it/contents/Scientific- } \\
\text { Research/Projects/oceans/enact1.ht } \\
\underline{\mathrm{ml}}\end{array}$ \\
\hline $\begin{array}{l}\text { DePreSys, } \\
\text { UK }\end{array}$ & OI & $\begin{array}{l}\text { SST, T \& S profiles from XBT, } \\
\text { CTD, Argo, TAO }\end{array}$ & $1950-2007$ & $\begin{array}{l}\text { http://www.ecmwf.int/research/EU } \\
\underline{\text { projects/ENSEMBLES/data/index. }} .\end{array}$ \\
\hline Reading, UK & OI with $\mathrm{S}(\mathrm{T})$ & $\begin{array}{l}\mathrm{T} \& \mathrm{~S} \text { profiles from } \mathrm{EN} 3 \text { and } \\
\text { Argo }\end{array}$ & $\begin{array}{l}1960-2007 \\
\text { at } 1^{\circ} \text { and } \\
1987-2007 \\
\text { at } 1 / 4^{\circ}\end{array}$ & www.resc.reading.ac.uk/godiva2 \\
\hline K-7, Japan & Adjoint & $\begin{array}{l}\text { Altimetry, SST, T from XBT, } \\
\text { CTD, Argo, TAO }\end{array}$ & $1960-2006$ & $\begin{array}{l}\text { www.jamstec.go.jp/frcgc/k-7- } \\
\text { dbase2/ }\end{array}$ \\
\hline MOVE-G, Japan & 3D-VAR & $\begin{array}{l}\text { Altimetry, SST, T \& S from } \\
\text { XBT, CTD, Argo, TAO }\end{array}$ & 1948-2007 & www.mri-jma.go.jp/Dep/oc/oc.html \\
\hline
\end{tabular}

Table 1. Brief summary of ocean state estimation systems

Many data types are routinely synthesized to produce ocean state estimates. The type and volume of data vary with systems. Previous studies have shown complementarity of different data types in improving ocean state estimates. For this reason, all systems use data from more than one observing system. Table 1 summarizes the observations synthesized by various systems. The most commonly used data are sea level anomaly from altimeters (e.g. TOPEX/Poseidon and JASON-1), in-situ temperature profiles (e.g. from XBT/CTD, TAO moorings, and Argo), and salinity profiles from Argo. The impact of the data constraint on the estimation can be seen from the reduction of modeldata misfit for the different observations as a result of the minimization procedure. Figure 1 is an example showing the reduction of model-data misfit as a result of the optimization of the ECCO-GODAE system. In this case, altimeter data, Argo T/S profiles, and SST data have relatively large impact on the estimation. Many of the ocean state estimation products are publically available through data servers (Table 1). A few recent studies have attempted to compare these products with a uniform set of observational data (e.g. Gemmell et al. 2009). In the future, it would be valuable to provide more misfit diagnostics (e.g. Fig. 1) for different synthesis products calculated in a uniform way against the same data. More details of the state estimation efforts can be found in CLIVAR GSOP web page http://www.clivar.org/organization/gsop/gsop.php.

\section{APPLICATIONS}

Ocean state estimation products and tools have been applied to studies over a wide range of topics in physical oceanography, for instance, the nature of sea level variability (e.g. Carton et al. 2005, Wunsch et al. 2007, Fukumori et al. 2007, Köhl and Stammer 2008a), water-mass pathways (e.g. Fukumori et al. 2004, Wang et al. 2004, Masuda et al. 2006, Toyoda et al. 2009), estimating surface fluxes and river runoff (e.g. Stammer et al. 2004, Romanova et al. 2009), and interannual and decadal variability of the upper-ocean and heat content (e.g. Masina et al. 2004, Capotondi et al. 2006, Köhl et al. 2007, Carton and Santorelli 2009). They have also been applied to research in other disciplines such as biogeochemistry (e.g. McKinley et al. 2000 and 2004, Dutkiewicz et al. 2001 and 2006) and geodesy (e.g. Ponte et al. 2001, Dickey et al. 2002 Chao et al. 2003, Gross et al. 2005). Due to limited space, here we only highlight a very limited number of examples for ocean circulation studies and discuss the implications for observing systems.

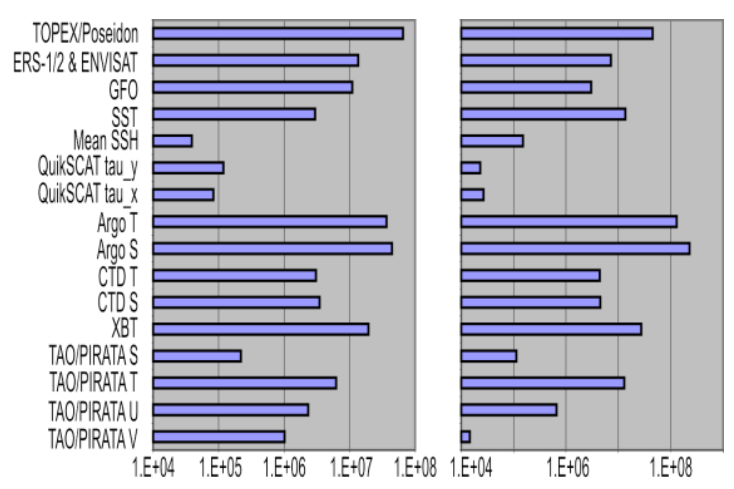

Figure 1. Non-dimensional model-data misfits (normalized by data error) in the ECCO-GODAE system after the optimization (left), and the reduction of the model-data misfits as a result of the optimization (right). The former is the components of the so-called cost function at the end of the optimization. The latter, describing the reduction of the cost function, reflects the impact of various data on obtaining the estimate. Courtesy of Patrick Heimbach of MIT and Ichiro Fukumori of JPL. 
Ocean state estimation products have been widely used to study the meridional overturning circulations (MOCs) as well as heat and freshwater transports, which are quantities that are difficult to measure directly (e.g. Stammer et al. 2003, Lee and Fukumori 2003, Schoenefeldt and Schott 2006, Wunsch and Heimbach 2006, Balmaseda et al. 2007, Köhl and Stammer 2008b, Schott et al. 2007 and 2008, Cabanes et al. 2008, Rabe et al. 2008, Volkov et al. 2008). These analyses often have direct implications to the observing systems. For instance, Lee and Fukumori (2003) and Schott et al. (2007) identified the anti-correlated variability of meridional pycnocline transports in the western boundaries and the interior associated with interannualdecadal variation of the Pacific subtropical cells (STC). Therefore, the low-latitude western boundary currents (LLWBCs) and interior flow play opposite roles in regulating upper-ocean heat content in the Pacific (with the interior flow being more dominant). Such an anticorrelated variability is associated with the oscillations of the tropical horizontal gyres in the western-central Pacific Ocean in response to near-local Ekman pumping. The oscillations of the tropical gyres and their forcing have signatures in sea level anomaly as observed by altimeters and wind stress curl captured by scatterometers (see Fig. 2 for altimeter data examples).
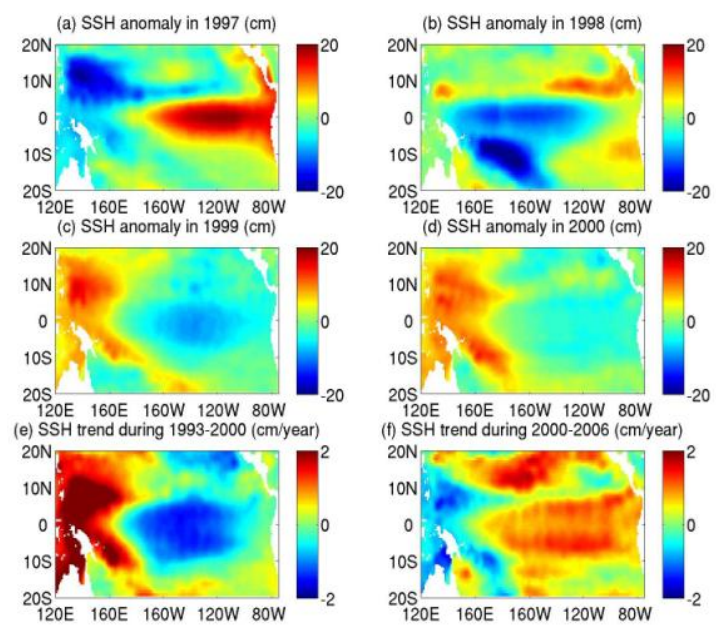

Figure 2. Interannual-to-decadal variability of SSH captured by TOPEX/Poseidon and JASON-1 altimeters imply oscillations of tropical gyres in the western tropical Pacific near $10^{\circ} \mathrm{N}$ and $10^{\circ} \mathrm{S}$, which result in counteracting variations of pycnocline transports in the interior and near the western boundaries (with the interior being more dominant). These data, presented by

Lee and Fukumori (2003) and Lee and McPhaden (2008), provide an effective constraint on the estimates of pycnocline flow variability in ocean state estimation, as discussed by Lee and Fukumori (2003) and Schott et al. (2007).
These signatures provide some constraint on the estimated partial compensation of the western-boundary and interior flows and thus tropical heat content. Nevertheless, the satellite data have footprints that are too coarse to resolve the sharp changes near the LLWBCs. Therefore, systematic measurements of the LLWBCs, which are not well resolved by existing insitu observing systems, would enhance the observational constraint on the state estimates.

Another example of the feedback between state estimation and observing system is the study of decadal variability of the North Atlantic MOC by Wunsch and Heimbach (2006), Balmaseda et al. (2007), Köhl et al., (2007), and Köhl and Stammer (2008). These studies discussed the complex structure of the estimated decadal variability in the MOC in depth and latitude. In the ECCO-GODAE estimate (Wunsch and Heimbach 2006), for instance, the decadal weakening of the upper meridional circulation (associated with reduced northward transport above $1200 \mathrm{~m}$ ) at $26^{\circ} \mathrm{N}$ is accompanied by a strengthening deep meridional circulation (i.e. the southward outflow of North Atlantic Deep Water and northward inflow of abyssal water) in the ECCO-GODAE estimate (Fig. 3). In the ECMWF operational analysis product (ORA-S3), there is a weakening northward flow (Balmaseda et al. 2007) at most latitudes of the North Atlantic basin.

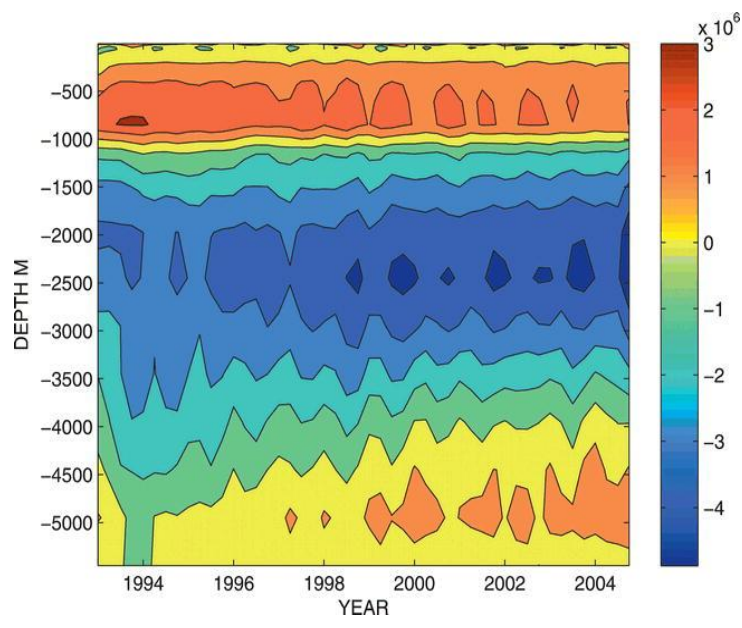

Figure 3. Seasonal averages (3 months) of volume transport contours $\left(\mathrm{m}^{3} \mathrm{~s}^{-1}\right)$ through time as a function of depth estimated by the ECCO-GODAE system. The weakening of the upper part of the meridional circulation (associated with the reduced Northward transport) is accompanied by a strengthening of the deeper meridional circulations (i.e., the southward outflow of North Atlantic Deep Water and northward inflow of abyssal water). After Wunsch and Heimbach (2006). 
At $50^{\circ} \mathrm{N}$, the northward transport is well correlated with the intensity of the subpolar gyre (which can be derived from altimeter data) at interannual-decadal time scales, but the trends are opposite. Data assimilation substantially improves the estimated time-mean strength of the MOC (Fig. 4). There is apparent agreement between the ECMWF analysis with the estimates by Bryden et al. (2005) based on synoptic hydrographic sections in the 1980s and 1990s. However, both Wunsch and Heimbach (2006) and Balmaseda et al. (2007) discussed the large month-to-month fluctuations in the MOC estimate, which could cause aliasing if sampled infrequently. Both studies showed that the trend in the meridional heat transport was smaller than that of the MOC strength because surface warming partially counteracted the weakening (upper) MOC. Therefore, an observing system that is capable of inferring changes in the volume transport may not be alone adequate to monitor the heat transport. These findings suggest that a systematic measurement network for the Atlantic MOC and heat transport at different latitudes (and different depths) beyond the traditional synoptic hydrographic survey are needed. The extension of such a system as the RAPID array is a step towards that direction (please refer to the white paper by Cunningham et al. (2007) on Atlantic MOC monitoring system). However, much of the ocean is still vastly under-sampled. The studies on decadal variation of the MOC re-emphasize the importance of having systematic, sustained, and consistent measurements of the global ocean circulation in general.

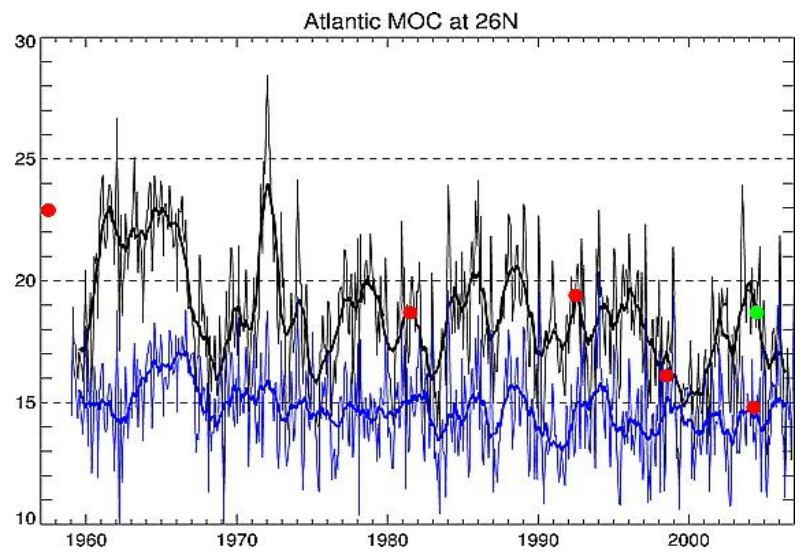

Figure 4. Meridional overturning circulation (MOC) variability at $26^{\circ} \mathrm{N}$ (in Sv). The time evolution of the $M O C$ for ECMWF's ocean reanalysis (black) and for the no-assimilation run (blue) is shown using monthly values (thin lines) and annual means (thick lines). Overplotted are the annual-mean MOC values from Bryden et al. (2005) based on synoptic hydrographic sections and Cunningham et al. (2007) based on RAPID mooring data (green circle). After Balmaseda et al. (2007).
With their near continuous measurements at fixed locations, mooring observations have provided a valuable source of data to constrain and evaluate state estimation products (see the white paper by McPhaden et al. (2010) for the global tropical buoy array). These data also allow local heat budget analyses near mooring sites (e.g. Wang and McPhaden 2000, McPhaden (2002)). Although not all the budget terms can be measured directly, the analysis are helpful for evaluating the budget of state estimation products, and they give better confidence for using these products to study the budget on larger scales, which are difficult to capture completely with mooring systems. The studies of mixed-layer temperature balance by Kim et al. (2004, 2007), Du et al. (2008), and Halkides and Lee (2009) are examples of the application of state estimation products for heat budget analysis. In particular, the dynamical consistency of ECCO estimates allows the heat budget to be closed because there are no internal sources or sink of heat being produced by the assimilation procedure.

Apart from the studies of ocean circulation, state estimation products and tools have also many other applications. For example, the estimation systems can be used to evaluate the impact of existing observations or the design of future observational systems (e.g. Oke and Schiller 2007). The use of ocean state estimation products to initialize seasonal climate forecasts has become an important routine practice in operational and experimental prediction centers. This subject is reviewed by the white paper by Balmaseda et al. As part of the CLIVAR/GODAE global ocean reanalysis evaluation efforts, many assimilation groups in the US, Europe, and Japan have participated in an effort to compare a suite of derived diagnostic quantities among different products and with observations. Among other goals, the ENSEMBLE analysis helps identify the minimum accuracy of observation that can distinguish the products or to constrain the estimation effectively. Stammer et al. (2010) is related to the intercomparison of various estimation products. Additional feedbacks of state estimation to observational requirements are addressed by Heimbach et al. (2010).

\section{CHALLENGES}

Despite significant advances in ocean state estimation, many challenges remain. The estimates of model and data errors dictate the outcome of the estimation product. Therefore, the ocean state estimation community needs to work closely with the observationalists to obtain robust estimates of data errors (including biases), an important issue that is often left to the hands of assimilation groups. A close collaboration with the modeling community is also needed to better understand model errors. The quantification of model errors is only one aspect. The 
identification of model error sources is critical to the estimation based on control theories. Some model errors are attributable to multiple sources. For example, a biased SST estimate in the equatorial Pacific cold tongue could be related to errors in wind, surface heat flux, or mixing parameterizations and advection (also related to resolution). Determination of the appropriate "controls" and correct attribution of error sources are important to the fidelity of the estimation products. Moreover, assimilation groups need to work closely with the modeling community to improve model physics, especially those associated with the bias in the mean state.

The estimation of decadal and longer-term variability remains a challenge due to the lack of observations on these time scales in the ocean and for the forcing fields and the insufficient understanding of the errors associated with these observations. This is compounded by the limitation in model physics. Sustained observations of the ocean and its forcing are therefore critical to the improvement of decadal and longer-term ocean state estimation.

Many of the state estimation products have resolutions that are too coarse to represent mesoscale eddies. As these eddies affect the climate through their interaction with the larger scales, it is imperative that ocean state estimation efforts move towards eddy-permitting resolutions, to more fully utilize the existing observations that capture eddy variability (e.g. the multi-altimeter system), and to develop the capability to synthesize future observations such as those from the Surface Water Ocean Topography (SWOT) mission. Computational resources remain a critical issue for estimation efforts that are based on ENSEMBLE or adjoint methods because they limit the ENSEMBLE size and model resolution that one can afford. Finally, the coupled nature of the climate system prompts for a coupled approach for state estimation that includes different components of the climate system (such as the ocean, atmosphere, land, cryosphere, and biogeochemistry) in order to properly account for the potential feedback among different components. Currently, coupled ocean-atmosphere, ocean-ice, and ocean physics-biogeochemistry state estimations are still in their infancy. Examples of emerging efforts include (NOAA) GFDL's use of ENSEMBLE Kalman filter (Zhang et al. 2007) and (Japan) K-7's use of adjoint method (Sugiura et al. 2008) to perform estimation using coupled ocean-atmosphere models. Coupled estimation efforts are expected to pick up momentum in the coming decade.

\section{SUMMARY}

Aided by the development of global ocean observing systems, significant accomplishments have been achieved in global ocean state estimation efforts that are aiming towards climate applications. A suite of global ocean state estimation products have been produced to describe the time evolving three-dimensional ocean circulation. There have been an ever increasing number of applications of these products for oceanographic and climate-related studies over a wide range of topics in physical oceanography and other disciplines. These studies provide important feedback to the requirement and design of the observing systems. The estimation systems need further improvement through a better understanding and quantification of model, data, and forcing errors, improved model physics and resolution, and the inclusion of other components of the climate system as part of the estimation. Despite these challenges, ocean state estimation remain a pivotal approach to understanding the climate system, and will be ever even more so in the future as we aim to quantify the feedbacks in the system and investigate longer time scales.

\section{REFERENCES}

1. Balmaseda, M.A., G.C. Smith, K. Haines, et al. 2007: Historical reconstruction of the Atlantic Meridional Overturning Circulation from the ECMWF operational ocean reanalysis. Geophys. Res. Lett., 34, L23615, doi:10.1029/2007GL031645.

2. Bahurel P., et al., 2006: MERCATOR OCEAN Global to regional ocean monitoring and forecasting. In "Ocean Weather Forecasting: An Integrated View of Oceanography”, E.P. Chassignet and J. Verron (Eds.), Springer, 381395.

3. Cabanes, C., T. Lee, and L.-L. Fu, 2008: Mechanisms of Interannual Variations of the Meridional Overturning Circulation of the North Atlantic Ocean. J. Phys. Oceanogr., 38, 467-480.

4. Capotondi A., A. Wittenberg, S. Masina, 2006. Spatial and temporal structure of ENSO in $20^{\text {th }}$ century coupled simulations. Ocean Modelling, 15, (3-4), 274-298 http://dx.doi.org/10.1016/j.ocemod.2006.02.004

5. Carton, J.A., B.S. Giese, and S.A. Grodsky, 2005: Sea level rise and the warming of the oceans in the Simple Ocean Data Assimilation (SODA) ocean reanalysis. J. Geophys. Res., 110, C09006, doi:10.1029/2004JC002817.

6. Carton, J.A. and A. Santorelli, 2009: Global Decadal Upper-Ocean Heat Content as Viewed in Nine Analyses. J. Clim., 21, 6015-6035.

7. Chao BF, Au AY, Boy JP, and et al., 2003: Timevariable gravity signal of an anomalous redistribution of water mass in the extratropic 
Pacific during 1998-2002, Geochem Geophys. Geosys. 4, Art. No. 1096.

8. Cunningham, S.A., T. Kanzow, and D. Rayner, et al., 2007: Temporal variability of the Atlantic meridional overturning circulation at 26.5 degrees N. Science, 317, 935-938.

9. Dickey, J. O., S. L. Marcus, O. de Viron, and I. Fukumori, 2002. Recent Earth oblateness variations: Unraveling climate and postglacial rebound effects, Science, 298, 1975-1977.

10. Du, Y, T.-D. Qu, and G. Meyers, 2008: Interannual variability of sea surface temperature off Java and Sumatra in a global GCM. J. Clim., 21, 11, 24512465.

11. Dutkiewicz, S., Follows, M., Marshall, J. and W. Gregg, 2001: Interannual variability in phytoplankton abundances in the North Atlantic. Deep-Sea Res. II, 48, 2323-2344.

12. Dutkiewicz, S., M.J. Follows, P. Heimbach and J. Marshall, 2006: Controls on ocean productivity and air-sea carbon flux: An adjoint model sensitivity study. Geophys. Res. Lett., 33, L02603, doi:10.1029/2005GL024987.

13. Fukumori, I., T. Lee, B. Cheng, and D. Menemenlis, 2004: The origin, pathway, and destination of NINO3 water estimated by a simulated passive tracer and its adjoint. J. Phys. Oceanogr., 34, 582604.

14. Fukumori, I., D. Menemenlis, T. Lee, 2007: A nearuniform basin-wide sea level fluctuation of the Mediterranean Sea. J. Phys. Oceanogr., 37, 338358.

15. Gemmell, A., Smith, G., Haines, K., Blower, J. (2009): Validation of ocean model syntheses against hydrography using a new web application, J.Op. Oceangr., 2 (2): 29-41.

16. Gross, R.S., I. Fukumori, and D. Menemenlis., 2005: Atmospheric and Oceanic Excitation of DecadalScale Earth Orientation Variations. J. Geophys. Res., 110, B09405, doi:10.1029/2004JB003565.

17. Halkides, D., and T. Lee, 2009: Mechanisms controlling seasonal-to-interannual mixed-layer temperature variability in the southeastern tropical Indian Ocean. J. Geophys. Res., 114, C02012, doi:10.1029/2008JC004949.

18. Heimbach, P. \& Co-Authors (2010). "Observational Requirements for Global-Scale Ocean Climate Analysis: Lessons from Ocean State Estimation" in these proceedings (Vol. 2), doi:10.5270/OceanObs09.cwp.42.
19. Kim, S.-B., T. Lee, and I. Fukumori, 2004: The 1997-99 abrupt change of the upper ocean temperature in the northcentral Pacific. Geophys. Res. Lett., 31, L22304, doi:10.1029/2004GL021142.

20. Kim, S.-B., T. Lee, I. Fukumori, 2007: Mechanisms controlling the interannual variation of mixed layer temperature averaged over the NINO3 region. $J$. Clim., 20, 3822-3843.

21. Köhl, A., D. Stammer, and B. Cornuelle, 2007: Interannual to decadal changes in the ECCO global synthesis. J. Phy. Oceanogr., 37, 313-337.

22. Köhl, A., and D. Stammer, 2008a: Decadal sea level changes in the 50-year GECCO ocean synthesis. $J$. Clim., 21, 1866-1890.

23. Köhl, A. and D. Stammer, 2008b: Variability of the meridional overturning in the North Atlantic from 50-year GECCO state estimation. J. Phys. Oceanogr., 38, 1913 -1930.

24. Lee, T., and I. Fukumori, 2003: Interannual to decadal variation of tropical-subtropical exchange in the Pacific Ocean: boundary versus interior pycnocline transports. J. Climate. 16, 4022-4042.

25. Lee, T., and M.J. McPhaden 2008: Decadal phase change in large-scale sea level and winds in the Indo-Pacific region at the end of the $20^{\text {th }}$ century. Geophys. Res. Lett., 35, L01605, doi:10.1029/2007GL032419.

26. Masina S., P. Di Pietro, A. Navarra A., 2004. Interannual-to-decadal variability of the North Atlantic from an ocean data assimilation system. Climate Dynamics, 23, 531-546. doi:10.1007/s00382-004-0453-6.

27. Masuda, S., T. Awaji, N. Sugiura, T. Toyoda, Y. Ishikawa, K. Horiuchi, 2006: Interannual variability of temperature inversions in the subarctic North Pacific, Geophys. Res. Lett., 33, doi:10.1029/2006GL027865.

28. McKinley, G. M.J. Follows and J. Marshall, 2000: Interannual variability of oxygen fluxes in the North Atlantic. Geo. Res. Letters., 27, 2933-2936.

29. McKinley, G., M.J. Follows and J. Marshall, 2004: Mechanisms of air-sea $\mathrm{CO} 2$ flux variability in the Equatorial Pacific and north Atlantic: Global Biogeochemical Cycles, vol 18, doi:10.1029/2003GB002179.

30. McPhaden, M.J., 2002: Mixed layer temperature balance on intraseasonal timescales in the equatorial Pacific Ocean. J. Clim., 15, 2632-2647. 
31. McPhaden, M. \& Co-Authors (2010). "The Global Tropical Moored Buoy Array" in these proceedings (Vol. 2), doi:10.5270/OceanObs09.cwp.61

32. Oke, P. R., and A. Schiller, 2007: A model-based assessment and design of a tropical Indian Ocean mooring array. J. Clim., 20, 3269-3283.

33. Ponte, R.M., D. Stammer and C. Wunsch, 2001: Improving ocean angular momentum estimates using a model constrained by data. Geophys. Res. Lett., 28, 1775-1778.

34. Rabe, B., F.A. Schott, and A. Köhl, 2008: Mean circulation and variability of the tropical Atlantic during 1952-2001 in the GECCO assimilation fields. J. Phy. Oceanogr., 38, 177-192.

35. Romanova, V., A. Köhl, D. Stammer, C. Klepp, A. Andersson and S. Bakan, 2010 "Surface freshwater flux estimates from GECCO and HOAPS", Tellus, 62, p. 435-452, doi:10.1111/j.16000870.2010.00447.x.

36. Schoenefeldt, R., and F. A. Schott, 2006: Decadal variability of the Indian Ocean cross-equatorial exchange in SODA. Geophys. Res. Lett., 33, L08602, doi:10.1029/2006GL025891.

37. Schott, F.A., W.-Q. Wang, and D. Stammer, 2007: Variability of Pacific subtropical cells in the 50year ECCO assimilation. Geophys. Res. Lett., 34, L05604, doi:10.1029/2006GL028478.

38. Schott, F.A., L. Stramma, W. Wang, et al., 2008: Pacific Subtropical Cell variability in the SODA 2.0.2/3 assimilation. Geophys. Res. Lett., 35, L10607, doi:10.1029/2008GL033757.

39. Stammer, D., C. Wunsch, I. Fukumori, and J. Marshall, 2002: State estimation improves prospects for ocean research. EOS, Transactions, American Geophysical Union, Vol. 83, Nr. 27, p. 289, 294--295.

40. Stammer, D., C. Wunsch, R. Giering, C. Eckert, P. Heimbach, J. Marotzke, A. Adcroft, C.N. Hill, and J. Marshall, 2002a: The global ocean circulation during 1992 -1997, estimated from ocean observations and a general circulation model. $J$. Geophys. Res., 107(C9), 3118, doi:10.1029/2001JC000888.

41. Stammer, D., C. Wunsch, and R. Giering, et al. 2003: Volume, heat, and freshwater transports of the global ocean circulation 1993-2000, estimated from a general circulation model constrained by World Ocean Circulation Experiment (WOCE) data. J. Geophys. Res., 108, 3007, doi:10.1029/2001JC001115.
42. Stammer, D., K. Ueyoshi, A. Köhl, W.B. Large, S. Josey, and C. Wunsch, 2004: Estimating Air-Sea Fluxes of Heat, Freshwater and Momentum Through Global Ocean Data Assimilation. J. Geophys. Res., 109, C05023, doi:10.1029/2003JC002082.

43. Stammer, D. 2005: Adjusting internal model errors through ocean state estimation. J. Phy. Oceanogr., $35,1143-1153$.

44. Stammer, D. \& Co-Authors (2010). "Ocean Information Provided Through Ensemble Ocean Syntheses" in these proceedings (Vol. 2), doi:10.5270/OceanObs09.cwp.85

45. Sugiura, N., T. Awaji, S. Masuda, et al. 2008: Development of a four-dimensional variational coupled data assimilation system for enhanced analysis and prediction of seasonal to interannual climate variations. J. Geophys. Res., 113, C10017, doi:10.1029/2008JC004741.

46. Toyoda, T., T. Awaji, S. Masuda, N. Sugiura, H. Igarashi, T. Mochizuki, and Y. Ishikawa, 2009: Interannual variability of North Pacific eastern subtropical mode water formation in the 1990s derived from a 4-dimensional variational ocean data assimilation experiment. J. Geophys. Res., submitted.

47. Volkov, D. L., T. Lee, and L.-L. Fu, 2008: Eddyinduced meridional heat transport in the ocean, Geophys. Res. Lett., doi:10.1029/2008GL035490.

48. Wang, W.M. and M.J. McPhaden, 2000: The surface-layer heat balance in the equatorial Pacific Ocean. Part II: Interannual variability. J. Phy. Oceanogr., 30, 2989-3008.

49. Wang, O., I. Fukumori, T. Lee, and B. Cheng, 2004 On the cause of eastern equatorial Pacific Ocean T-S variations associated with El Nino. Geophys. Res. Lett., 31, L15310, doi:10.1029/2004GL02472.

50. Wunsch, C. and P. Heimbach, 2006: Estimated decadal changes in the North Atlantic meridional overturning circulation and heat flux 1993-2004. J. Phys. Oceanogr., 36, 11, 2012-2024.

51. Wunsch, C., R.M. Ponte, P. Heimbach, 2007: Decadal trends in sea level patterns: 1993-2004. J. Clim., 20, 5889-5911.

52. Zhang, S., M.J. Harrison, A. Rosati et al, 2007: System Design and Evaluation of Coupled Ensemble Data Assimilation for Global Oceanic Studies. Mon. Wea. Rev., 135, 3541-3564. 